\title{
A survey of quality control practices for high dose rate (HDR) and pulsed dose rate (PDR) brachytherapy in the United Kingdom
}

\author{
Antony L. Palmer, MSc'.2, Margaret Bidmead, MSc ${ }^{3}$, Andrew Nisbet, PhD ${ }^{1.4}$ \\ IDepartment of Physics, Faculty of Engineering and Physical Science, University of Surrey, Guildford, GU2 7XH, UK, 2Medical Physics \\ Department, Queen Alexandra Hospital, Portsmouth Hospitals NHS Trust, Portsmouth, PO6 3LY, UK, ${ }^{3}$ Medical Physics Department. \\ The Royal Marsden NHS Foundation Trust, London, SW3 6JJ, UK, 4 Medical Physics Department, Royal Surrey County Hospital \\ NHS Foundation Trust, Guildford, UK
}

\begin{abstract}
Purpose: A survey of quality control (QC) currently undertaken in UK radiotherapy centres for high dose rate (HDR) and pulsed dose rate (PDR) brachytherapy has been conducted. The purpose was to benchmark current accepted practice of tests, frequencies and tolerances to assure acceptable HDR/PDR equipment performance. It is 20 years since a similar survey was conducted in the UK and the current review is timed to coincide with a revision of the IPEM Report 81 guidelines for quality control in radiotherapy.

Material and methods: All radiotherapy centres in the UK were invited by email to complete a comprehensive questionnaire on their current brachytherapy QC practice, including: equipment type, patient workload, source calibration method, level of image guidance for planning, prescribing practices, QC tests, method used, staff involved, test frequencies, and acceptable tolerance limits.

Results: Survey data was acquired between June and August 2012. Of the 64 centres invited, 47 (73\%) responded, with 31 centres having brachytherapy equipment (3 PDR) and fully completing the survey, 13 reporting no HDR/PDR brachytherapy, and 3 intending to commence HDR brachytherapy in the near future. All centres had comprehensive QC schedules in place and there was general agreement on key test frequencies and tolerances. Greatest discord was whether source strength for treatment planning should be derived from measurement, as at $58 \%$ of centres, or from the certified value, at $42 \%$. IPEM Report 81 continues to be the most frequently cited source of QC guidance, followed by ESTRO Booklet No. 8 .

Conclusions: A comprehensive survey of QC practices for HDR/PDR brachytherapy in UK has been conducted. This is a useful reference to which centres may benchmark their own practice. However, individuals should take a risk-assessment based approach, employing full knowledge of local equipment, clinical procedures and available test equipment in order to determine individual QC needs.

Key words: high dose rate (HDR), brachytherapy, quality control (QC), quality assurance (QA), survey.

\section{Purpose}

The dosimetric accuracy of brachytherapy delivery is fundamental to the achievement of clinical treatment aims, tumour control and minimised normal tissue toxicity. As early as 1993 Van Dyk et al. [1] defined a requirement for brachytherapy treatment delivery of $3 \%$ accuracy in dose at distances of $0.5 \mathrm{~cm}$ or more at any point for any radiation source. Control of dose delivery is particularly difficult to achieve in brachytherapy due to small treatment distances, very high dose gradients and a multitude of aspects that affect accuracy [2]. A quality assurance system in radio-

therapy is essential to ensure treatment delivery is consistent and as intended. This will include a multitude of quality control (QC) tests designed to evaluate actual operating performance in comparison to goal values and to enable rectification/reconciliation of any differences.

Brachytherapy is currently undergoing a period of significant innovation and rapid modernisation [3], including a shift from 2D to 3D basis [4], the enhanced use of imaging [5], patient-specific treatment plan optimisation, fully volume-based prescribing [6], inverse-planning [7], advanced planning algorithms [8], use of advanced treatment applicators $[9,10]$, and in-vivo dosimetry verification systems
\end{abstract}


[11]. It is essential that QC test schedules keep pace with the changing technology and clinical practice. This includes re-assessing the use of historic $\mathrm{QC}$ tests that are no longer fit for purpose and replacing with more relevant $\mathrm{QC}$, or where system performance is verified by other means avoiding unnecessary redundancy.

Quality assurance of all brachytherapy techniques has recently received increased attention following low dose rate brachytherapy incident in 2009 at the Philadelphia VA Medical Centre in which a number of patients received poor quality prostate seed brachytherapy treatment [12]. There have also been errors in brachytherapy due to confusion of source strength units, including incorrect entry into treatment planning systems [13]. In addition, there are numerous publications on more subtle equipment-related quality issues in high dose rate (HDR) delivery, such as unexpected, irregular spacing of source dwell positions in ring applicators [14]. It is important that QC testing is robust and comprehensive and meets the needs of modern equipment and treatment techniques.

It is over twenty years since a comprehensive assessment has been undertaken of brachytherapy QC practice in the United Kingdom (UK): reproduced in the Institute of Physics and Engineering in Medicine (IPEM) Report 81 [15]. The IPEM guidance on QC for radiotherapy is currently being revised, and it is therefore timely to undertake a repeat benchmark exercise of current QC practice for brachytherapy. The present survey has been endorsed by the IPEM Radiotherapy Special Interest Group. A similar survey was conducted in 2002 in the Netherlands and Belgium [16], which reported large variations in test frequencies and methods, and differences in QC-philosophy and available equipment. The authors are unaware of any contemporary comparisons of brachytherapy QC practice.

The publication of a comprehensive assessment of current QC practice has several potential benefits for individual radiotherapy departments: centres may be reassured that their QC systems are in-line with accepted practice; alternatively, centres may identify discrepancies against standards of practice. Following investigation, this may lead to either reduction of tests or frequencies and hence efficiency savings, or resolution of deficiencies and potential improvements in safety and quality. However, the details of QC tests presented here should not be interpreted as guidelines or recommendations, but as a 'snapshot' of current UK practice. It is important to be aware that specific QC testing is a local decision, based on many local factors, and should ideally be based on risk-assessment approaches.

\section{Material and methods}

All 64 radiotherapy centres in the UK were contacted by email in June 2012 to request their contribution to the study, with collation of responses taking place during June to August 2012. Centres were asked to complete a detailed questionnaire on their routine QC practices and other aspects of HDR and PDR service provision. To enable a contextual review of QC practice, initial questions were asked included equipment type, average patient workload, sites treated, source strength calibration methods, level of image guidance, and prescribing practice. A spreadsheet containing a comprehensive list of possible quality control tests for treatment and planning equipment was also provided. Centres were asked to document whether they routinely perform each test, at what frequency, by which staff group, and the acceptable tolerance values used. They were also asked to comment whether the target test frequencies were actually achieved in practice.

\section{Results \\ Equipment profile and general physics aspects of brachytherapy service}

Forty-seven (73\%) of the $64 \mathrm{UK}$ radiotherapy centres that were invited to take part in the survey of HDR and PDR QC responded. Thirty-one centres had appropriate brachytherapy equipment and provided fully completed questionnaires on their QC practice. Thirteen centres reported no HDR or PDR brachytherapy facilities, and further 3 intended to commence HDR brachytherapy in the near future. The majority (29) of radiotherapy centres had HDR units, with only three having access to PDR treatments, two having exclusively PDR. The equipment profile of the responding centres included 20 Nucletron/Elekta microSelectron, 7 Varian GammaMed, 4 Nucletron/Elekta/Isodose Control Flexitron, 1 Eckert \& Ziegler Bebig HDR Multisource, and 1 Varian Varisource. One centre had 3 treatment units, $1 \mathrm{HDR}$ and 2 PDR, all others had 1 unit. One centre had a Co-60 source (HDR), the others were all using Ir-192. The latter isotope being exchanged at 3-monthly intervals in all but two centres: one at 4-monthly intervals and another PDR centre at between 3 and 6 months. One centre stated they were considering moving to 4-monthly intervals to reduce cost. The planned frequency of exchange for the Co-60 source was 4 years. The mean number of HDR fractions delivered per year at each centre was 281 , with interquartile range 173 to 359 (minimum 80 and maximum 730).

There was a lack of agreement as to whether the locally measured value or the manufacturer's supplied source certificate should be used for the source strength value in treatment planning calculations; 18 centres (58\%) preferring to use their own measurement. The current UK Code of Practice for HDR brachytherapy dosimetry [5] recommends a well chamber for the primary source strength measurement, but allows some flexibility in the method used to obtain the second independent verification value. Table 1 lists methods used for source calibration and their relative popularity within UK centres.

The quoted origin of the TG-43 [18] source model data used in the treatment planning systems also varied between centres. Fourteen $(45 \%)$ used the supplied manufacturer data, 8 (26\%) used journal published data, and 8 (26\%) used manufacturer data and verified this against publications (with 1 (3\%) not answering the question). There was also a variety of methods quoted as an independent check of the output of the treatment planning system. The methods and their popularity are given in Table 2 .

Treatment plan optimisation in some form was used in 23 centres $(73 \%)$, including for cervix (majority), prostate (next most common), skin/limb moulds, interstitial anus, 
Table 1. Methods employed and their popularity, for source strength measurement of HDR \& PDR sources at centres in UK

Technique for determination of source strength

Number of centres Percentage of centres

\begin{tabular}{llcc}
\hline Initial method & Well chamber & 29 & 94 \\
\cline { 2 - 4 } Manufacturer supplied source certificate & 1 & 3 \\
\cline { 2 - 4 } Verification method & We2571 chamber with in-air jig & 1 & 3 \\
\cline { 2 - 4 } & NE2571 chamber with in-air jig & 14 & 45 \\
\cline { 2 - 4 } & NE2571 chamber in solid phantom & 12 & 39 \\
\cline { 2 - 4 } & Manufacturer supplied source certificate & 2 & 3 \\
\cline { 2 - 4 } & I-125 seed device with adaptor & 1 & 3
\end{tabular}

Table 2. Methods employed and their popularity, to independently verify treatment planning system (TPS) calculations at centres in UK

\begin{tabular}{lcc} 
Technique for verification of TPS calculation & Number of centres & Percentage of centres \\
\hline $\begin{array}{l}\text { Locally developed check software (including systems based on Matlab, Excel, Java, } \\
\text { visual basic; usually employing either TG43 [18] or BIR/IPSM 1993 [20]) }\end{array}$ & 16 & 52 \\
\hline $\begin{array}{l}\text { Commercial check software or additional TPS (including IMSure QA, Radcalcbrachy, } \\
\text { Lifeline) }\end{array}$ & 7 & 23 \\
\hline Manual calculation or use of data tables & 3 & 10 \\
\hline Nomogram (prostate treatment) or TRAK relationship to target volume & 2 & 6 \\
\hline Use of standard plans only with initial independent calculation, no per-patient plan verification & 2 & 6 \\
\hline Consistency check performed with standard plan on same day & 1 & 3
\end{tabular}

Table 3. Primary sources of guidance for establishing QC schedules and their popularity at centres in UK Documents providing guidance on HDR or PDR QC

Number of centres citing document
Percentage of centres citing document

\begin{tabular}{lll}
\hline Physics aspects of quality control in radiotherapy, IPEM Report 81 [21] & 19 & 61 \\
\hline A practical guide to quality control of brachytherapy equipment, ESTRO Booklet No. 8 [22] & 15 & 48 \\
\hline $\begin{array}{l}\text { The IPEM code of practice for the determination of the reference air kerma rate for HDR } \\
\text { (192)Ir brachytherapy sources based on the NPL air kerma standard, 2010 [17] }\end{array}$ & 10 & 32 \\
\hline Code of practice for brachytherapy physics, AAPM TG-56, 1997 [23] & 8 & 26 \\
\hline Discussion with colleagues and other centres' documents & 6 & 19 \\
\hline High dose-rate brachytherapy treatment delivery, AAPM TG-59, 1998 [24] & 4 & 13 \\
\hline Recommendations for Brachytherapy Dosimetry, BIR/IPSM Report 1993 [20] & 10 \\
\hline Calibration of photon and beta ray sources used in brachytherapy, IAEA TecDoc 1274, 2002 [25] & 3 & 10 \\
\hline Quality assurance for clinical radiotherapy treatment planning, AAPM TG-53, 1998 [26] & 2 & 6 \\
\hline Quality assurance tests for prostate brachytherapy ultrasound systems, AAPM TG-128, 2008 [27] & 2 & 6 \\
\hline Manufacturer's guidance or manual & 2 & 6 \\
\hline A revised AAPM protocol for brachytherapy dose calculations, AAPM TG-43U1, 2004 [18] & 2 & 6 \\
\hline Thomadsen BR 'Achieving quality in brachytherapy’, 1999 [28] & 2 & 6 \\
\hline Other radiotherapy or brachytherapy text books, each $n=1$ & 2 & 3 \\
\hline Remote afterloading technology, AAPM TG-41, 1993 [29] & 1 & 3 \\
\hline Towards Safer Radiotherapy, joint report of RCR, SoR, CoR, IPEM, NPSA, BIR, 2008 [30] & 1 & 3 \\
\hline In-house experience with treatment unit & 1 & 3 \\
\hline Quoted 'Relevant regulations' & 1 & 3 \\
\hline Quoted ‘Unsure of origin’ & 1 & 6 \\
\hline
\end{tabular}


vaginal vault, lung, head \& neck, multilumen mammosite breast, intraluminal, and keloid scars. Twenty-seven centres $(87 \%)$ optimised treatment plans for individual patients; 19 (61\%) employing manual methods and the others inverse planning optimisation, often with final manual adjustment. 6 centres (19\%) stated they used pre-optimised standard plan libraries.

The level of image-guidance varied significantly between centres. In cervix treatments, $16(52 \%)$ used CT alone for treatment planning, 12 (39\%) MRI with CT, 2 (6\%) MRI alone, and 1 (3\%) c-arm 2D imaging alone. When MRI was available this was often used for the first fraction, with CT used in subsequent treatments. For vaginal vault treatments, $13(42 \%)$ did not image, 10 (32\%) used orthogonal 2D X-ray, and $8(26 \%)$ used CT. Some centres responded they would only image vault treatments for complex cases or if individualised plans were required. There were an insufficient number of responses on imaging used for other treatment sites for statistical significance.

Gynaecology cancers were the most commonly treated. In cervix, 22 centres (71\%) still prescribe treatment doses to Manchester Point A. For those prescribing instead to highrisk clinical target volume, HR-CTV [19], all centres additionally record the Point A dose. Only 2 centres $(6 \%)$ exclusively recorded ICRU organ at risk (OAR) point doses, likely when only orthogonal imaging is used, the others recorded either just GEC-ESTRO dose-volume histogram (DVH) data $(48 \%)$, or both ICRU point dose and DVH data (46\%).

Centres were asked to list the primary sources of guidance used in establishing their HDR or PDR quality control schedules. Table 3 provides a list of the documents that were indicated and their popularity, quoted as the percentage of centres citing the document. All centres stated they had reviewed the content of their HDR/PDR QC schedule within the last two years, except two which did not answer the question.

\section{Quality control tests}

Table 4 provides detail from the HDR and PDR QC survey. The table shows the percentage of centres that include each of the specific tests in their planned QC schedules. A centre is deemed to have included the test in their regular QC if it is performed within the department whether it is in the specific 'physics QC documentation' or other 'standard operating procedures', for plan checking for example. A test is deemed not to be in regular QC if it was only intended to be performed once at initial equipment commissioning. The mean and range of frequencies of testing and acceptable tolerance levels are provided in the Table. There is a significant variation in consistency between centres across the range of tests. Inclusion of tests in QC schedules varies from 31 centres $(100 \%)$ for source strength measurements to just 2 centres $(6 \%)$ for MRI tests, the latter of course being due to limitations of access to MRI for brachytherapy-specific clinical use and QC testing (it was not recorded how many centres routinely used MRI for brachytherapy planning). The consistency of frequency of testing and acceptable tolerance levels also varies markedly between the individual QC tests, between complete or lack of agreement for specific tests. Of the 45 tests includ- ed in the survey, 21 were performed at greater than $75 \%$ of centres, and 4 were performed at less than $25 \%$ of centres. There were no significant differences in the QC techniques employed for HDR and PDR equipment, and certainly within the range of practice between centres. Only 2 centres $(6 \%)$ reported achieved measurement frequencies were below planned measurement frequencies, and then only for up to two tests each.

Table 5 documents additional QC tests suggested by responding centres, which were not included in the original list of tests in the distributed survey. These are generally proposals made by single centres and there is no information of the popularity of these tests across UK, however they are included for interest.

Quality control testing of dosimetry equipment associated with HDR and PDR use has not been included in the results tables; secondary standard calibrations and consistency testing of well chambers and Farmer-type ionisation chambers, which are covered elsewhere and in published codes of practice [17].

\section{Discussion}

The survey data presented in this report represents the current practice in the majority of brachytherapy centres within the UK. Whilst there is a high level of consistency in inclusion, frequency and tolerance values for some tests, such as source strength measurement, there are varied responses to other tests. This is likely due to differences in local planning and treatment procedures in clinical use, availability of equipment, and differing functionality or performance of equipment. Local assessment of QC needs is essential in determining schedules, rather than simple reliance on the 'majority view'. However, benchmarking against accepted practice is a good starting point for local review. A risk assessment approach including local known factors is advocated for final decisions on QC testing. All schedules must include measurement of source strength, source position and dwell time, but the specific details require knowledge of local clinical practice and equipment in use.

While there was some variation in staff groups involved in QC testing between centres, physics staff most commonly performed all of the QC tests except facilities testing (Table 4) which was almost exclusively performed by radiographers. Within each centre, a specific QC test may be performed in multiple ways, including staff group involved, equipment used, frequency of measurement, and tolerance value. Each different measurement method has been included in the results table. For example, 'decay correction accuracy at treatment unit' may be performed prior to each patient treatment by radiographers, and separately by radiotherapy physics after each source change, but to a tighter investigation tolerance level. The achievable tolerance value for this test is also dependent on the equipment design, whether the software makes hourly corrections for source decay or 12-hourly for example. The standard operating procedures of individual departments also have a significant affect on the QC testing that is performed. This includes all aspects such as whether optimised or standard/tabulated planning is used, whether 2D or 3D imaging is utilised, and whether electronic transfer of data is available. An independent method for the verification of the accuracy of treat- 
Table 4. HDR \& PDR QC survey: response to questionnaire on test popularity, measurement frequency and tolerance values

\begin{tabular}{|c|c|c|c|c|c|}
\hline & QC test & $\begin{array}{l}\text { \% of centres } \\
\text { including } \\
\text { in routine } \\
\text { QC }\end{array}$ & $\begin{array}{l}\text { Measurement intervals } \\
\% \text { using mean value } \\
\text { (and range of } \\
\text { responses) }\end{array}$ & $\begin{array}{l}\text { Tolerance } \\
\% \text { using mean } \\
\text { value (and range } \\
\text { of responses) }\end{array}$ & Comments \\
\hline \multirow{4}{*}{ 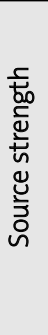 } & $\begin{array}{l}\text { Initial measurement after } \\
\text { source installation }\end{array}$ & 100 & $\begin{array}{l}100 \% \text { at source change } \\
\text { (all centres) }\end{array}$ & $\begin{array}{l}52 \% \text { use } 3 \% \\
(2 \% \text { to } 5 \%)\end{array}$ & \multirow{4}{*}{$\begin{array}{l}\text { Achievable tolerance depends } \\
\text { on test method and whether } \\
\text { result is compared to certifi- } \\
\text { cate or } 1^{\text {st }} \text { measurement }\end{array}$} \\
\hline & $\begin{array}{l}\text { Independent measurement } \\
\text { after source installation }\end{array}$ & 100 & $\begin{array}{l}100 \% \text { at source change } \\
\text { (all centres) }\end{array}$ & $\begin{array}{l}35 \% \text { use } 3 \% \\
(0.5 \% \text { to } 5 \%)\end{array}$ & \\
\hline & $\begin{array}{l}\text { Repeat measurements during } \\
\text { life of source }\end{array}$ & 75 & $83 \%$ at $1 \mathrm{~m}(1 \mathrm{~d}$ to $1 \mathrm{~m})$ & $\begin{array}{l}56 \% \text { use } 3 \% \\
(0.5 \% \text { to } 5 \%)\end{array}$ & \\
\hline & Leak testing of source & 97 & $\begin{array}{l}97 \% \text { at source change } \\
\text { (1 } \mathrm{m} \text { to source change) }\end{array}$ & $\begin{array}{l}71 \% \text { not }>\text { background } \\
\text { (zero to } 200 \mathrm{~Bq} \text { ) }\end{array}$ & \\
\hline \multirow{7}{*}{ 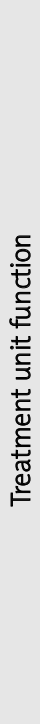 } & $\begin{array}{l}\text { Confirm accuracy of source } \\
\text { data at treatment unit }\end{array}$ & 97 & $\begin{array}{l}41 \% \text { at each patient } \\
\text { (each patient to com- } \\
\text { missioning only) }\end{array}$ & $\begin{array}{l}55 \% \text { use exact match } \\
\text { (exact to } 4 \% \text { ) }\end{array}$ & \\
\hline & $\begin{array}{l}\text { Confirm accuracy of decay } \\
\text { correction at treatment unit } \\
\text { for plans }\end{array}$ & 91 & $\begin{array}{l}86 \% \text { at each patient } \\
\text { (weekly to com- } \\
\text { missioning only) }\end{array}$ & $\begin{array}{l}22 \% \text { use } 1 \% \\
\text { (exact match to } 3 \% \text { ) }\end{array}$ & $\begin{array}{l}\text { Tolerance depends on how } \\
\text { frequently unit makes decay } \\
\text { correction }\end{array}$ \\
\hline & Plan data transfer from TPS & 83 & $\begin{array}{l}96 \% \text { at each patient } \\
\text { (weekly to commis- } \\
\text { sioning only) }\end{array}$ & $\begin{array}{l}63 \% \text { use exact match } \\
(0.1 \mathrm{~s} \text { to } 2 \%)\end{array}$ & $\begin{array}{l}\text { Some standard template } \\
\text { plans not electronically } \\
\text { transferred }\end{array}$ \\
\hline & $\begin{array}{l}\text { Simulated treatment } \\
\text { functionality test }\end{array}$ & 68 & $68 \%$ at $1 \mathrm{~d}(1 \mathrm{~d}$ to $12 \mathrm{~m})$ & $\begin{array}{l}50 \% \text { use } 1 \mathrm{~mm} \\
(1 \mathrm{~mm} \text { to } 2 \mathrm{~mm} \text { ) }\end{array}$ & $\begin{array}{l}\text { May be independent test } \\
\text { or combined }\end{array}$ \\
\hline & $\begin{array}{l}\text { System display and print-out } \\
\text { accurate and in agreement }\end{array}$ & 96 & $\begin{array}{l}83 \% \text { at each patient } \\
\text { (each patient to com- } \\
\text { missioning only) }\end{array}$ & $\begin{array}{l}88 \% \text { use exact match } \\
\text { (exact to } 2 \% \text { ) }\end{array}$ & \\
\hline & $\begin{array}{l}\text { Test of function with mains } \\
\text { power loss }\end{array}$ & 58 & $50 \%$ at $3 \mathrm{~m}$ ( $1 \mathrm{~m}$ to $12 \mathrm{~m})$ & & \\
\hline & $\begin{array}{l}\text { Test of uninterruptable power } \\
\text { supply (UPS) }\end{array}$ & 44 & $31 \%$ at $3 \mathrm{~m}(1 \mathrm{~d}$ to $12 \mathrm{~m})$ & & \\
\hline \multirow{10}{*}{ 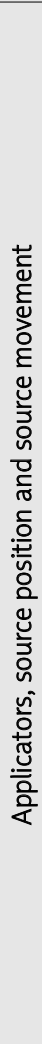 } & $\begin{array}{l}\text { Visual inspection of applicators } \\
\text { and transfer tubes for damage }\end{array}$ & 97 & $70 \%$ at $1 \mathrm{~d}(1 \mathrm{~d}$ to $12 \mathrm{~m})$ & & \\
\hline & $\begin{array}{l}\text { Measurement of dimensions } \\
\text { and angles of applicators and } \\
\text { transfer tubes }\end{array}$ & 48 & $\begin{array}{l}46 \% \text { at commissioning } \\
\text { (each patient to } 12 \mathrm{~m} \text { ) }\end{array}$ & $\begin{array}{l}75 \% \text { use } 1 \mathrm{~mm} \\
(0.5 \mathrm{~mm} \text { to } 1 \mathrm{~mm})\end{array}$ & $\begin{array}{l}\text { Often rely on image } \\
\text { match to TPS library }\end{array}$ \\
\hline & X-ray imaging of applicators & 32 & $\begin{array}{l}64 \% \text { at commissioning } \\
(3 \mathrm{~m} \text { to } 12 \mathrm{~m})\end{array}$ & $100 \%$ use $1 \mathrm{~mm}$ & $\begin{array}{l}\text { Most commonly only when } \\
\text { suspected damage }\end{array}$ \\
\hline & $\begin{array}{l}\text { Verification of source dwell } \\
\text { timer accuracy }\end{array}$ & 97 & $38 \%$ at $1 \mathrm{~d}(1 \mathrm{~d}$ to $12 \mathrm{~m})$ & $\begin{array}{l}38 \% \text { use } 1 \mathrm{~s} \\
(0.1 \mathrm{~s} \text { to } 2 \mathrm{~s})\end{array}$ & $\begin{array}{l}\text { Large variation in definition } \\
\text { of test methodology }\end{array}$ \\
\hline & $\begin{array}{l}\text { Measurement of source dwell } \\
\text { positions in straight catheter } \\
\text { (not clinical applicator) }\end{array}$ & 100 & $42 \%$ at $1 \mathrm{~d}(1 \mathrm{~d}$ to $4 \mathrm{~m})$ & $\begin{array}{l}78 \% \text { use } 1 \mathrm{~mm} \\
(0.5 \mathrm{~mm} \text { to } 2 \mathrm{~mm})\end{array}$ & $\begin{array}{l}\text { Multiple techniques often } \\
\text { in use at each centre }\end{array}$ \\
\hline & $\begin{array}{l}\text { Measurement of source dwell } \\
\text { positions in clinical applicators }\end{array}$ & 55 & $\begin{array}{l}36 \% \text { at commissioning } \\
(2 \mathrm{w} \text { to } 12 \mathrm{~m})\end{array}$ & $\begin{array}{l}79 \% \text { use } 1 \mathrm{~mm} \\
(1 \mathrm{~mm} \text { to } 2 \mathrm{~mm})\end{array}$ & \\
\hline & $\begin{array}{l}\text { Measurement of actual source } \\
\text { dwell positions compared to TPS } \\
\text { stated position in complex geo- } \\
\text { metry e.g. ring applicator }\end{array}$ & $S$ & $\begin{array}{l}35 \% \text { at } 3 \mathrm{~m} \\
\text { ( } 2 \mathrm{w} \text { to commissioning) }\end{array}$ & $\begin{array}{l}67 \% \text { use } 1 \mathrm{~mm} \\
(1 \mathrm{~mm} \text { to } 3 \mathrm{~mm})\end{array}$ & $\begin{array}{l}\text { Absence of test often due } \\
\text { to ring applicator not being } \\
\text { used }\end{array}$ \\
\hline & $\begin{array}{l}\text { Source position relative to } \\
\text { dummy source or marker wire }\end{array}$ & 60 & $\begin{array}{l}35 \% \text { at commissioning } \\
\text { (1 } \mathrm{d} \text { to } 12 \mathrm{~m} \text { ) }\end{array}$ & $\begin{array}{l}72 \% \text { use } 1 \mathrm{~mm} \\
(0.5 \mathrm{~mm} \text { to } 2 \mathrm{~mm})\end{array}$ & $\begin{array}{l}\text { Absence of test normally due } \\
\text { to marker wire not being used }\end{array}$ \\
\hline & $\begin{array}{l}\text { Applicator/transfer tube } \\
\text { connection interlock and } \\
\text { simulated error }\end{array}$ & 73 & $68 \%$ at $1 \mathrm{~d}(1 \mathrm{~d}$ to $6 \mathrm{~m})$ & & \\
\hline & $\begin{array}{l}\text { Verification of expected position } \\
\text { of internal applicator shielding }\end{array}$ & 15 & $\begin{array}{l}50 \% \text { at each patient } \\
\text { (each patient to com- } \\
\text { missioning) }\end{array}$ & & Not commonly in use in UK \\
\hline
\end{tabular}


Table 4. Cont.

\begin{tabular}{|c|c|c|c|c|c|}
\hline & $\begin{array}{l}\% \\
\text { in } \\
\text { in }\end{array}$ & $\begin{array}{l}\% \text { of centres } \\
\text { including } \\
\text { in routine } \\
\text { QC }\end{array}$ & $\begin{array}{l}\text { Measurement intervals } \\
\% \text { using mean value } \\
\text { (and range of } \\
\text { responses) }\end{array}$ & $\begin{array}{l}\text { Tolerance } \\
\% \text { using mean } \\
\text { value (and range } \\
\text { of responses) }\end{array}$ & Comments \\
\hline & $\begin{array}{l}\text { Measurement of source } \\
\text { transit times }\end{array}$ & 47 & $\begin{array}{l}41 \% \text { at } 3 \mathrm{~m} \\
\text { (1 w to commissioning) }\end{array}$ & $\begin{array}{l}\text { No consistency, } \\
\text { responses were: } \\
0.1 \mathrm{~s},<0.5 \mathrm{~s},<1 \mathrm{~s} \text {, } \\
\text { not }>\text { baseline, not } \\
>0.05 \mathrm{~s} \text { dwell equivalent }\end{array}$ & $\begin{array}{l}\text { Large variety of tech niques } \\
\text { (well chamber to stop watch) } \\
\text { and tolerance values } \\
\text { t }\end{array}$ \\
\hline & $\begin{array}{l}\text { Confirm error code 'meanings } \\
\text { and actions' are available at } \\
\text { treatment unit }\end{array}$ & 36 & $\begin{array}{l}25 \% \text { each at } 1 \mathrm{~d} \text { and } 12 \mathrm{~m} \\
\text { (1d to commissioning) }\end{array}$ & & $\begin{array}{l}\text { Historic test, mostly replaced } \\
\text { with improved software inter- } \\
\text { face information }\end{array}$ \\
\hline & $\begin{array}{l}\text { Radiation monitor of applicators } \\
\text { after use }\end{array}$ & 26 & $\begin{array}{l}86 \% \text { at each patient } \\
\text { (each patient to } 1 \mathrm{w} \text { ) }\end{array}$ & $\begin{array}{l}100 \% \text { not above } \\
\text { background }\end{array}$ & $\begin{array}{l}\text { Majority rely on in-room radia- } \\
\text { tion monitor }\end{array}$ \\
\hline \multirow{5}{*}{ 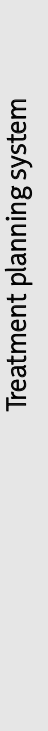 } & $\begin{array}{l}\text { Accuracy of source model data } \\
\text { used by TPS (e.g. check TG-43 } \\
\text { data against reference values) }\end{array}$ & 36 & $\begin{array}{l}65 \% \text { at commissioning } \\
\text { ( } 1 \mathrm{~m} \text { to commissioning) }\end{array}$ & $\begin{array}{l}\text { No consistency } \\
\text { (interpolation to 5\%) }\end{array}$ & $\begin{array}{l}\text { Normally undertaken at } \\
\text { software updates }\end{array}$ \\
\hline & $\begin{array}{l}\text { Accuracy of individual source } \\
\text { data used by TPS (e.g. source } \\
\text { strength, calibration date) }\end{array}$ & 89 & $\begin{array}{l}64 \% \text { at each patient } \\
\text { (each patient to } 3 \mathrm{~m} \text { ) }\end{array}$ & $\begin{array}{l}\text { No consistency, } \\
\text { responses were: } \\
\text { exact match, rounding } \\
\text { error, } 1 \text { day correction, } \\
0.5 \%, 1 \%, 2 \%, 3 \%\end{array}$ & $\begin{array}{l}\text { Tolerance may depend on how } \\
\text { frequently unit makes decay } \\
\text { correction }\end{array}$ \\
\hline & $\begin{array}{l}\text { Calculation of standard plans } \\
\text { compared to reference data }\end{array}$ & 63 & $\begin{array}{l}28 \% \text { at } 3 \mathrm{~m} \\
\text { (1 d to commissioning) }\end{array}$ & $\begin{array}{l}\text { No consistency, } \\
\text { responses were: exact } \\
\text { match, } 1 \%, 2 \%, 3 \%, 5 \% \text {, } \\
1 \mathrm{~mm} \text { idsodose lines }\end{array}$ & \\
\hline & $\begin{array}{l}\text { Independent check calculation } \\
\text { of TPS patient plans or standard } \\
\text { plans }\end{array}$ & 62 & $\begin{array}{l}74 \% \text { at each patient } \\
\text { (each patient to } \\
\text { commissioning) }\end{array}$ & $\begin{array}{l}50 \% \text { use } 3 \% \\
(1 \% \text { to } 5 \%)\end{array}$ & $\begin{array}{l}\text { Depends whether patient- } \\
\text { specific optimised or standard } \\
\text { plans are in use }\end{array}$ \\
\hline & $\begin{array}{l}\text { Repeat of tests performed at TPS } \\
\text { commissioning (e.g. DVH accuracy, } \\
\text { geometric tests) }\end{array}$ & y, & $\begin{array}{l}39 \% \text { at } 3 \mathrm{~m} \\
\text { (1 m to commissioning) }\end{array}$ & $\begin{array}{l}33 \% \text { use } 2 \mathrm{~mm} \\
\text { (variety of definitions } \\
\text { including } \mathrm{mm} \text {, \% of DVH } \\
\text { or dose points) }\end{array}$ & $\begin{array}{l}\text { Often performed at software } \\
\text { updates only }\end{array}$ \\
\hline \multirow{5}{*}{ 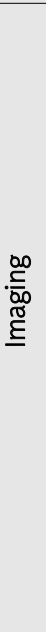 } & $\begin{array}{l}\text { 2D kV imaging tests, including } \\
\text { applicator reconstruction }\end{array}$ & 24 & $\begin{array}{l}29 \% \text { at } 1 \mathrm{~d} \\
\text { (1 d to commissioniong) }\end{array}$ & $\begin{array}{l}50 \% \text { use } 2 \% \text { ( } 1 \% \text { to } 2 \% \text {, } \\
\text { or } 2 \mathrm{~mm})\end{array}$ & $\begin{array}{l}\text { Absence of test often due } \\
\text { to } 2 \mathrm{D} \text { imaging not being used }\end{array}$ \\
\hline & $\begin{array}{l}\text { CT imaging tests, including } \\
\text { applicator reconstruction }\end{array}$ & 38 & $\begin{array}{l}\text { 50\% at commissioning } \\
\text { (each patient to com- } \\
\text { missioning) }\end{array}$ & $\begin{array}{l}\text { No consistency, res- } \\
\text { ponses were: } 1 \%, 2 \% \text {, } \\
3 \%, 5 \%, 1 \mathrm{~mm}, 2 \mathrm{~mm}\end{array}$ & $\begin{array}{l}\text { Absence of specific tests often } \\
\text { due to reliance on TPS applica- } \\
\text { tor library }\end{array}$ \\
\hline & $\begin{array}{l}\text { MR imaging tests, including } \\
\text { applicator reconstruction and } \\
\text { distortion }\end{array}$ & 6 & $\begin{array}{l}60 \% \text { at commissioning } \\
(3 \mathrm{~m} \text { to commissioning) }\end{array}$ & $\begin{array}{l}50 \% \text { use } 2 \mathrm{~mm} \\
(1 \mathrm{~mm} \text { to } 2 \mathrm{~mm})\end{array}$ & $\begin{array}{l}\text { Absence of test often due } \\
\text { to brachytherapy-specific } \\
\text { MR imaging not being used } \\
\text { Access to MR for QC often } \\
\text { a problem }\end{array}$ \\
\hline & $\begin{array}{l}\text { Ultrasound imaging tests, } \\
\text { including applicator reconstruction } \\
\text { and grid alignment }\end{array}$ & 26 & $\begin{array}{l}43 \% \text { at } 3 \mathrm{~m} \\
\text { (1 m to commissioning) }\end{array}$ & $\begin{array}{l}\text { No consistency, } \\
\text { responses were: } \\
1 \mathrm{~mm}, 2 \mathrm{~mm}, 1 \mathrm{cc}, 5 \%\end{array}$ & $\begin{array}{l}\text { Absence of test often due } \\
\text { to ultrasound imaging not } \\
\text { being used }\end{array}$ \\
\hline & $\begin{array}{l}\text { Accuracy of image data transfer } \\
\text { to TPS }\end{array}$ & 60 & $\begin{array}{l}27 \% \text { at each patient } \\
\text { (each patient to } \\
\text { commissioning) }\end{array}$ & $\begin{array}{l}43 \% \text { use exact match } \\
\text { (exact to } 2 \mathrm{~mm} \text {, or } 2 \% \text { ) }\end{array}$ & Image-based data only \\
\hline \multirow{3}{*}{ 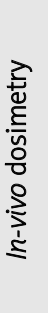 } & $\begin{array}{l}\text { Availability of in-vivo dosimetry } \\
\text { system for brachytherapy? }\end{array}$ & 19 & & & \multirow{3}{*}{$\begin{array}{l}\text { Not in clinical use in the ma- } \\
\text { jority of centres. Included TLD, } \\
\text { diode, MOSFET }\end{array}$} \\
\hline & $\begin{array}{l}\text { Calibration of in-vivo dosimetry } \\
\text { system }\end{array}$ & $\begin{array}{c}60 \\
\text { (of 19) }\end{array}$ & $\begin{array}{l}50 \% \text { at } 1 \mathrm{~m} \\
\text { (1 m to 'as required') }\end{array}$ & $100 \%$ use $5 \%$ & \\
\hline & $\begin{array}{l}\text { Test of in-vivo measurement } \\
\text { against expected/planned dose } \\
\text { measured in phantom }\end{array}$ & $\begin{array}{l}60 \% \\
\text { (of 19) }\end{array}$ & $50 \%$ each at $1 \mathrm{w}$ and $12 \mathrm{~m}$ & $100 \%$ use $5 \%$ & \\
\hline
\end{tabular}


Table 4. Cont.

\begin{tabular}{|c|c|c|c|c|c|}
\hline & $\begin{array}{c}\% \\
\text { in } \\
\text { ir }\end{array}$ & $\begin{array}{l}\% \text { of centres } \\
\text { including } \\
\text { in routine } \\
\text { QC }\end{array}$ & $\begin{array}{l}\text { Measurement intervals } \\
\% \text { using mean value } \\
\text { (and range of } \\
\text { responses) }\end{array}$ & $\begin{array}{l}\text { Tolerance } \\
\% \text { using mean } \\
\text { value (and range } \\
\text { of responses) }\end{array}$ & Comments \\
\hline \multirow{5}{*}{ 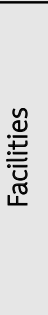 } & $\begin{array}{l}\text { Visual (CCTV) and audible } \\
\text { (intercom) patient monitoring }\end{array}$ & 100 & $\begin{array}{l}93 \% \text { at } 1 \mathrm{~d} \\
(1 \mathrm{~d} \text { to } 3 \mathrm{~m})\end{array}$ & functional & \\
\hline & Radiation warning lights & 100 & $90 \%$ at $1 \mathrm{~d}(1 \mathrm{~d}$ to $4 \mathrm{~m})$ & functional & \\
\hline & $\begin{array}{l}\text { Independent radiation monitor } \\
\text { (room monitor) }\end{array}$ & 100 & $83 \%$ at $1 \mathrm{~d}(1 \mathrm{~d}$ to $4 \mathrm{~m})$ & functional & \\
\hline & Interlocks (e.g. door, timer delay) & 100 & $90 \%$ at $1 \mathrm{~d}(1 \mathrm{~d}$ to $4 \mathrm{~m})$ & functional & \\
\hline & Emergency stop control & 100 & $81 \%$ at $1 \mathrm{~d}(1 \mathrm{~d}$ to $4 \mathrm{~m})$ & functional & \\
\hline \multirow{3}{*}{ 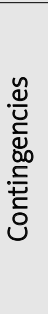 } & $\begin{array}{l}\text { Practice of simulated emergency } \\
\text { (e.g. source stuck) }\end{array}$ & 97 & $\begin{array}{l}46 \% \text { at } 12 \mathrm{~m} \\
(1 \mathrm{w} \text { to } 12 \mathrm{~m})\end{array}$ & & \\
\hline & $\begin{array}{l}\text { Presence of emergency equipment } \\
\text { (e.g. source container, forceps, } \\
\text { shield, monitor) }\end{array}$ & ht 97 & $\begin{array}{l}91 \% \text { at } 1 \mathrm{~d} \\
(1 \mathrm{~d} \text { to } 12 \mathrm{~m})\end{array}$ & & \\
\hline & $\begin{array}{l}\text { Review of responsibilities } \\
\text { (e.g who removes applicator } \\
\text { if source stuck) }\end{array}$ & 84 & $\begin{array}{l}50 \% \text { at } 1 \mathrm{~d} \\
(1 \mathrm{~d} \text { to } 12 \mathrm{~m})\end{array}$ & & \\
\hline
\end{tabular}

Table 5. HDR \& PDR QC survey: additional tests identified by responding centres, not included in original survey questionnaire

\begin{tabular}{|c|c|}
\hline Additic & nal possible QC tests not included in the survey \\
\hline & Dwell time linearity \\
\hline 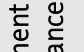 & Check behaviour if transfer tube loop/curvature too tight \\
\hline 을 & Treatment interruption behaviour \\
\hline 㞻枈 & Source drive motor operational (check audible indication of movement) \\
\hline & Satisfactory performance of system self-test \\
\hline & PDR pulse timing \\
\hline 哭 & Check of nurses' station and remote control panels \\
\hline$\underline{a}$ & Cathether integrity and connectivity to PDR unit \\
\hline & Partial treatment completion \\
\hline$\bumpeq$ & Consistency of plans between software version \\
\hline & Data security including backup (patient information, source data, system settings) \\
\hline$\stackrel{\text { ti }}{\varepsilon}$ no & Image fusion CT/MR \\
\hline$\underline{\underline{E}} \cdot \bar{c}$ & MR image scaling \\
\hline & Radiation monitoring of treatment unit (e.g. dose rate at $5 \mathrm{~cm}$ or $1 \mathrm{~m}$ ) \\
\hline 产 $\frac{0}{t}$ & Radiation monitor empty treatment unit during source change \\
\hline 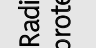 & Receipt and return of source paperwork \\
\hline & Confirm controls in place for source security \\
\hline Other & External audit of system quality control/performance \\
\hline
\end{tabular}

ment plans is required for individually-optimised treatments, but may not be required for each patient if a standard plan is used that has previously been verified and is checked for consistency.

Some tests are adopted by all centres such as 'source strength measurement' and 'source position in a straight catheter'. However, others such as 'X-ray imaging of appli- cators' is undertaken by only $32 \%$ of centres. The difference may be attributed to whether the process is already being assessed by alternative means, and there is some evidence from the survey to support this. For applicator dimensions and angles, a specific measurement may not be necessary if the consistency of shape is evaluated through agreement to planning system library applicators used for each indi- 
vidually-planned treatment (provided both physical applicator and library applicator have already been tested at commissioning). Checking of the $1^{\text {st }} \mathrm{dwell}$ position should however be verified in this case.

The number of centres including a routine measurement of actual source dwell positions in clinical applicators was surprisingly low, at 17 centres (55\%). Such testing should be performed at commissioning and at regular intervals, particularly if ring applicators are in use, in which the actual and TPS planned dwell positions should be compared.

IPEM Report 81 [21] was the most frequently cited document used for guidance on required HDR or PDR QC tests, but it is surprising that only $61 \%$ of UK centres cited this document, being the UK professional body's recommendations for QC. This may be because the document is now quite dated. More recent, but again surprisingly cited by only $48 \%$ of centres is the ESTRO Booklet No. 8 [22]. There is a large range in the documents identified by individual centres as their primary sources of guidance for QC testing, supporting the need for an update of IPEM Report 81 in UK.

\section{Conclusions}

A benchmark data set of brachytherapy HDR and PDR QC testing has been presented which is representative of practice across the UK. This updates a previous survey conducted over twenty years ago. A modern approach to QC is required to ensure continued safety and highest quality brachytherapy into the future as technology and procedures continue to increase in complexity, alongside increasing workforce pressures. QC testing schedules must be designed intelligently, including risk-based assessments of need rather than simply maintaining historic tests. The contents of this report should not be interpreted as professional advice as to the requirements of a brachytherapy $\mathrm{QC}$ schedule and are presented as a benchmark data set. Local decisions on QC testing must be made based on full risk-assessment and local factors.

\section{Acknowledgments}

We gratefully acknowledge the 47 radiotherapy centres in the UK that responded to this survey and in particular the staff from the 31 centres that completed the detailed questionnaire of QC practices for HDR \& PDR brachytherapy. We also thank Laura Gandon for her review of the quality control survey questionnaire.

\section{References}

1. Van Dyk J, Barnett RB, Cygler JE et al. Commissioning and quality assurance of treatment planning computers. Int J Radiat Oncol Biol Phys 1993; 20: 261-273.

2. Palmer A, Bradley D, Nisbet A. Physics-aspects of dose accuracy in high dose rate (HDR) brachytherapy; source dosimetry, treatment planning, equipment performance and in vivo verification techniques. J Contemp Brachyther 2012; 4: 81-91.

3. Potter R, Kirisits C. Upcoming ICRU/GEC ESTRO recommendations for brachytherapy in cancer of the cervix (1). Radiother Oncol 2012; 103: S42.

4. Hepel JT, Wazer DE. A comparison of brachytherapy techniques for partial breast irradiation. Brachytherapy 2012; 11: 163-175.
5. Haie-Meder C, Siebert FA, Potter R. Image guided, adaptive, accelerated, high dose brachytherapy as model for advanced small volume radiotherapy. Radiother Oncol 2011; 100: 333-343.

6. Wanderas AD, Sundset M, Langdal I et al. Adaptive brachytherapy of cervical cancer, comparison of conventional point A and CT based individual treatment planning. Acta Oncol 2012; 51: 345-354.

7. Siauw T, Cunha A, Atamturk A et al. IPIP: a new approach to inverse planning for HDR brachytherapy by directly optimizing dosimetric indices. Med Phys 2011; 38: 4045-4051.

8. Rivard MJ, Venselaar JLM, Beaulieu L. The evolution of brachytherapy treatment planning. Med Phys 2009; 36: 21362153.

9. Bernstein M, Mehta KJ, Yaparpalvi R et al. Results of the hybrid interstitial-intracavitary Utrecht applicator for cervical cancer in an outpatient setting. Radiother Oncol 2012; 103: S116.

10. Song W, Webster M, Han D et al. Dynamic modulated brachytherapy (DMBT): concept, design, and simulations. Radiother Oncol 2012; 103: S44-45.

11. Suchowerska N, Jackson M, Lambert J et al. Clinical trials of a urethral dose measurement system in brachytherapy using scintillation detectors. Int J Radiat Oncol Biol Phys 2011; 79: 609-615.

12. Daigh JD. Healthcare Inspection Review of Brachytherapy Treatment of Prostate Cancer, Philadelphia, Pennsylvania and Other VA Medical Centers. In: Department of Veterans Affairs, Office of Inspector General, Washington 2010.

13. United States Nuclear Regulatory Commission. NRC Information Notice 2009-17: Reportable medical events involving treatment delivery errors caused by confusion of units for the specification of brachytherapy sources. NRC, Washington 2009; available at: http:// pbadupws.nrc.gov/docs/ML0807/ ML080710054.pdf (accessed 31/08/12).

14. Stern RL, Liu T. Dwell position inaccuracy in the Varian GammaMed HDR ring applicator. J Appl Clin Med Phys 2010; 11: 291-296.

15. IPEM Radiotherapy Physics Topic Group, Survey of Quality Control Practice in UK Hospitals. Scope 1992; 1: 49-61. In: Mayles WPM, Lake R, McKenzie A, Macaulay EM, Morgan HM, Jordan TJ, Powley SK (eds.). Physics aspects of quality control in radiotherapy. Report no. 81. IPEM, York 1999.

16. Elfrink RJM, Kolkman-Deurloo IKK, van Kleffens HJ et al. Quality control of brachytherapy equipment in the Netherlands and Belgium; current practice and minimum requirements. Radiother Oncol 2001; 62: 95-102.

17. Bidmead AM, Sander T, Locks SM et al. The IPEM code of practice for determination of the reference air kerma rate for HDR (192)Ir brachytherapy sources based on the NPL air kerma standard. Phys Med Biol 2010; 55: 3145-3159.

18. Rivard MJ, Coursey BM, DeWerd LA et al. Update of AAPM Task Group No. 43 Report: A revised AAPM protocol for brachytherapy dose calculations. Med Phys 2004; 31: 633-674.

19. Potter R, Haie-Meder C, Limbergen EV et al. Recommendations from gynaecological (GYN) GEC ESTRO working group (II): concepts and terms in 3D image-based treatment planning in cervix cancer brachytherapy - 3D dose volume parameters and aspects of 3D image-based anatomy, radiation physics, radiobiology. Radiother Oncol 2006; 78: 67-77.

20. Aird EGA, Jones $\mathrm{CH}$, Joslin $\mathrm{CAF}$ et al. Recommendations for brachytherapy dosimetry. Report of a joint working party of the BIR and the IPSM. BIR, London 1993.

21. Mayles WPM, Lake R, McKenzie A et al. (eds.). Physics aspects of quality control in radiotherapy. Report no. 81. IPEM, York 1999.

22. Vanselaar J, Perez-Calatayud J (eds.). A Practical guide to quality control of brachytherapy equipment. ESTRO Booklet No. 8 . ESTRO, Brussels 2004 
23. Nath R, Anderson LL, Meli JA et al. Code of practice for brachytherapy physics: Report of the AAPM Radiation Therapy Committee Task Group No. 56. Med Phys 1997; 24: 1557-1598.

24. Kubo HD, Glasgow GP, Pethel TD et al. High dose-rate brachytherapy treatment delivery; report of the AAPM radiation therapy committee task group no. 59. Med Phys 1998; 25: 375403.

25. International Atomic Energy Agency, Dosimetry and Medical Radiation Physics Section. Calibration of photon and beta ray sources used in brachytherapy. IAEA-TECDOC-1274. IAEA, Vienna 2002.

26. Fraass B, Doppke K, Hunt M et al. American association of physicists in medicine radiation therapy committee task group 53: quality assurance for clinical radiotherapy treatment planning. Med Phys 1998; 25: 1773-1829.

27. Pfeiffeera D, Sutlief S, Feng W et al. AAPM task group 128: quality assurance tests for prostate brachytherapy ultrasound systems. Med Phys 2008; 35: 5471-5489.

28. Thomadsen BR. Achieving Quality in Brachytherapy. Taylor \& Francis, Madison 1999.

29. Glasgow GP, Bourland JD, Grigsby PW et al. A report of AAPM task group no. 41 remote afterloading technology. AAPM, New York 1993.

30. The Royal College of Radiologists, Society and College of Radiographers, Institute of Physics and Engineering in Medicine, National Patient Safety Agency, British Institute of Radiology. Towards Safer Radiotherapy. The Royal College of Radiologists, London 2008; available at: https:/ / www.rcr.ac.uk/docs/oncology/pdf/Towards_saferRT_final. pdf (accessed 24/09/12) 